University of Rhode Island

DigitalCommons@URI

The Rhode Island Current Conditions Index

Economics

$11-2007$

\title{
Rhode Island Current Conditions Index - November 2007
}

Leonard Lardaro

University of Rhode Island, lardaro@uri.edu

Follow this and additional works at: https://digitalcommons.uri.edu/ricci

Part of the Econometrics Commons

Terms of Use

All rights reserved under copyright.

\section{Recommended Citation}

Lardaro, Leonard, "Rhode Island Current Conditions Index - November 2007" (2007). The Rhode Island Current Conditions Index. Paper 62.

https://digitalcommons.uri.edu/ricci/62

This Article is brought to you for free and open access by the Economics at DigitalCommons@URI. It has been accepted for inclusion in The Rhode Island Current Conditions Index by an authorized administrator of DigitalCommons@URI.For more information, please contact digitalcommons-group@uri.edu. 


\section{GURRENT}

\section{BDNDIIDNS}

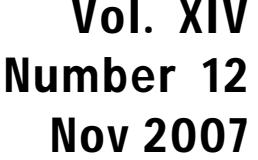

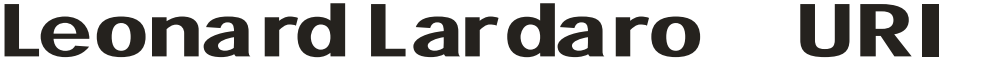

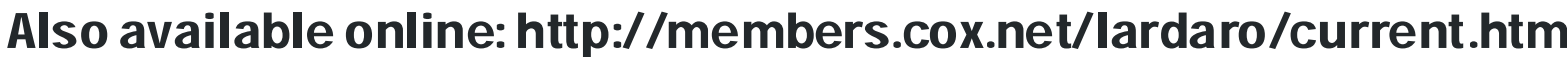

November was another disappointing month for Rhode Island's economy. The Current Conditions Index registered in the contracting range for the fourth consecutive month after posting a neutral value in July. This is recession performance. But it must be understood that recessions have stages. In the early stages of a recession, where I believe Rhode Island currently finds itself, the levels of indicators are not terribly different from those during recoveries. With the passing of time, however, come the later recession stages, where conditions continually deteriorate as indicators fall to lower and lower levels. This is what most people associate in general with recessions. Eventually a bottom is reached, which signals the end of the recession and the beginning of a recovery. For the US, if it is currently in recession (I continue to think it is not), recovery would begin in the second half of this year. For Rhode Island, the boost it gets from this improving national activity will be largely blunted by the necessity of dealing with a large budget deficit starting on July 1 . Timing really is everything!

Like the past several months, economic weakness continues to be spread across all sectors. And, as I have noted for the last few months, many of the non-improving indicators can be expected to retain that status for some time to come. Things got worse this month since an indicator that had been

\begin{tabular}{lr}
\multicolumn{2}{c}{ CCI I ndicators - \% Change } \\
Government Employment & -0.8 \\
US Consumer Sentiment & -17.2 \\
Single-Unit Permits & -29.8 \\
Retail Sales & -0.9 \\
Employment Services J obs & -11.4 \\
Priv. Serv-Prod Employment & 1.2 Y \\
Total Manufacturing Hours & -2.2 \\
Manufacturing Wage & 4.2 Y \\
Labor Force & 0.5 Y \\
Benefit Exhaustions & 13.1 \\
New Claims & 12.9 \\
Unemployment Rate & 2.0 \\
\multicolumn{1}{c}{ Y = I mproved Value } &
\end{tabular}

improving for some time, the Unemployment Rate, failed to improve. Expect this to continue for some time in the future. And, one irony continued: despite the overall weakness in Rhode Island's economy, the Manufacturing Wage grew at its fastest rate in years $(+4.2 \%)$ signaling skill shortages in manufacturing!

All of the $\mathrm{CCl}$ 's leading indicators failed to improve again. Employment Service Jobs, which includes "temp" positions, fell at a double-digit rate again in November $(-11.4 \%)$, its fourth consecutive monthly decline and a long way from its string of double-digit increases that extended from October 2006 through March of 2007. New Claims, rose (note: we want this to fall) again for the eleventh time in the last twelve months, even after an econometric adjustment for recent changes in benefit eligibility by senior citizens. Single-Unit Permits, which reflects new home construction, fell by 29.8 percent compared to last November. Its level remains at around 100 units per month. The last leading indicator, Total Manufacturing Hours, fell again (by $2.2 \%$ ), as manufacturing weakness moderated. Manufacturing weakness in Rhode Island appears to be less severe than it is nationally at the present time.

Other indicators continue to turn in disappointing performances. Along with our ongoing declines in housing, weakness in consumer sentiment and retail trade remains. US Consumer Sentiment fell by 17.2 percent in November, while Retail Sales continued its downward trend, falling by 0.9 percent. Private Service-Producing Employment growth remained sluggish. It is one of the few improving indicators that remain. And, to nobody's surprise, Government Employment fell again in November $(-0.8 \%)$.

Finally, our Labor Force grew at a slightly faster rate in November $(+0.5 \%)$. This, too, remains as one of the only indicators with a positive trend.

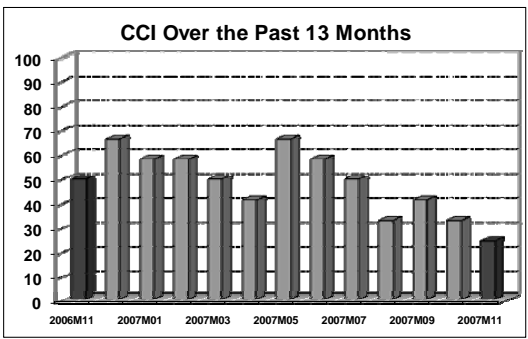

\section{THE BOTTOM LINE}

At this point, I believe Rhode Island is indeed in the early stages of a recession. The overall performance of the $\mathrm{CCl}$ and its leading indicators will not be improving any time soon. Add to this a weak national economy and the likelihood of our state being in a recession is even greater. Eliminating budget deficits will only exacerbate the length and severity of this recession.

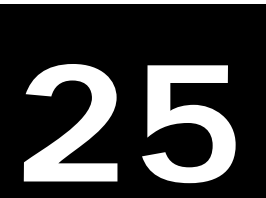

\begin{tabular}{|c|c|c|c|} 
& \multicolumn{1}{c}{ Jan } & Feb \\
2006 & 58 & 58 & 58 \\
\cline { 2 - 4 } 2007 & 58 & 58 &
\end{tabular}

Mar Apr

May Jun

\begin{tabular}{|c|c|c|c|c|c|}
\hline Jul & \multicolumn{1}{c}{ Aug } & \multicolumn{1}{c|}{ Sep } & \multicolumn{1}{c|}{ Oct } & \multicolumn{1}{c}{ Nov } & Dec \\
\hline 33 & 50 & 67 & 75 & 50 & 67 \\
\hline 50 & 33 & 42 & 33 & 25 & \\
\hline
\end{tabular}

